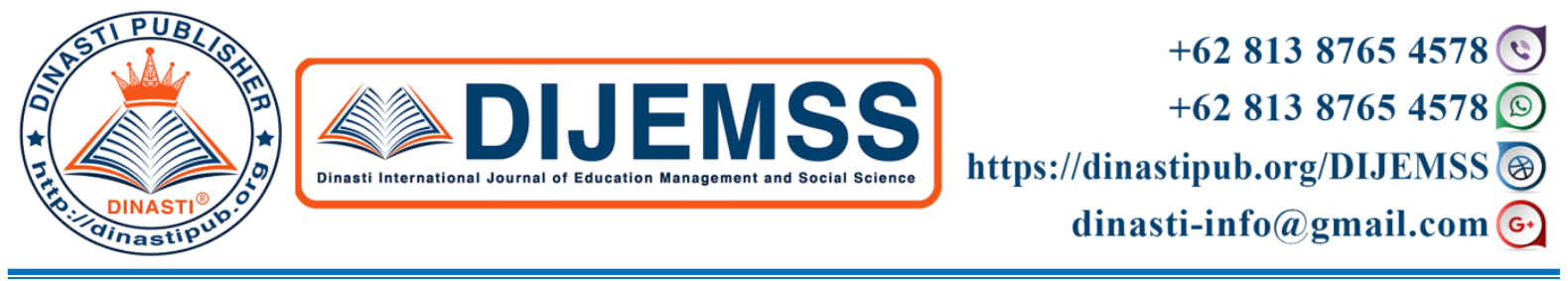

\title{
THE ROLE OF HUMAN RESOURCES IN DETERMINING EXCHANGE RATE FOR FARMERS OF FOOD CROPS IN EAST TANJUNG JABUNG REGENCY JAMBI PROVINCE
}

\author{
Saiyid Syekh ${ }^{1}$ \\ ${ }^{1)}$ Batanghari University, Jambi, Indonesia
}

ARTICLE INFORMATION

Received: $16^{\text {th }}$ June 2020

Revised: $25^{\text {th }}$ July 2020

Issued: $22^{\text {th }}$ August 2020

Corresponding author: first author E-mail:

sayid.wr1@gmail.com

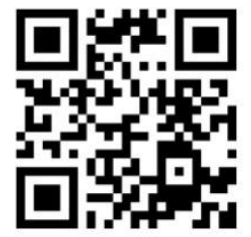

DOI:10.31933/DIJEMSS
Abstract: The research to porpose : (1) to know the farmers exchange rate in East Tanjung Jabung Regency; (2). To identify and analyze the determining factors of the exchange rate of farmers in East Tanjung Jabung Regency. (3). To analyse the role of HR (human resources) the exchange rate of farmers in East Tanjung Timur regency. This research used survey methode with porposive sampling in sub district: population of sub district in East TanjungJabung are 11 sub district, with sample amounth 5 sub district. The resulth of this research farmer's of food crops exchange rate in East Tanjung Jabung is at a point close to one hundred. This means that although farmers are still categorized as profit in the cultivation of agricultural crops and horticultural but the condition is very risky, because in addition to only comparable, also if subsidies and various assistance is not there, then farmers will tend to lose, except the district Geragai which farmers exchange rate its above $150 \%$. Human Resourches role is very dominant because in addition can manage the efforts ranging from preharbest handling to post Harberst handling.

Keywords: Farmers Exchnge Rate; farmers revenue and expendeture of farmers from cropt.

\section{INTRODUCTION}

Community welfare has always been a priority for national development. Improved community welfare is demonstrated by the improvement of various indicators of human resource development, including an increase in per capita income; Poverty alluviation and unemployment rate. 
Human Resources (SDM) plays an important role in an organization including agriculture, it is necessary as an effort to lead towards professionality in order to materialize a balance between the needs of farmers with the desire and ability of farmers themselves.

Implementation of agricultural development is essentially aimed at improving the welfare of the community especially farmers. Therefore, in every stage of agricultural development activities the welfare of farmers has always been a developmental goal of government. Through a variety of policies and agricultural development programs, the Government has sought to increase agricultural production, maintain the stability of food supply, and increase the income/welfare of farmers.

Among the development activities that have been underway are believed to be a lot of success achieved, especially in increasing production, rural economy as well as for rural and urban consumers. The other side poverty is still a problem that hasn't been completely solved, especially poverty in the countryside. Increased production of agricultural products through various technological and institutional engineering is assessed not enough to increase the income, welfare of farmers and in rural poverty (Dillon et al., 1999; Simatupang et al., 2000). This condition is supported by data indicating the number of poor people in Indonesia, especially in rural areas.

East Tanjung Jabung Regency is a region in Jambi Province which also conducts development activities with various relevant policies. The agricultural sector is a dominating sector in its economy. The development of agricultural sector contributions to Product Domistict Regional Bruto district of East Tanjung Jabung Regency showed an increasing percentage of $12.68 \%$ in 2012 to $19.04 \%$ in 2017 (district statitistical Center Board. East Tanjung Jabung, 2018). In addition, the agricultural sector is still a sector that absorbs the greatest workforce in East Tanjung Jabung Regency. The number of workers working in this sector is as much as 50,636 people from a total of 71,322 people or 71\% (Sakernas, District statitistical Center Board. East Tanjung Jabung,, 2018).

Agricultural development is oriented towards improving the welfare of development actors, especially farmers who are engaged in the cultivation of food crops and horticultural crops. One indicator/measuring instrument that can be used to assess the welfare level of farmers is the index of farmers exchange rate (NTP). farmers exchange rate is a measure of the ability to buy power/exchange of farmers on goods purchased by farmers. The increase in the farmer's exchange rate shows the increase in the farmer's real ability and indicates improvement in farmer welfare, or vice versa. In-depth knowledge of farmers ' behavioral exchange rates, development impacts, and identification of exchange rate factors will be very useful for development policy planning, improvement of development programs ahead.

Acceptance is identical with the level of farmers welfare where one of the indices commonly used to mirror it is the farmer's exchange rate (NTP). In this case there may be a link between the farmer's exchange rate and the condition of poverty so that there needs to be a study concerning the factors that determine the farmers exchange rate and its influence on poverty in order to be determined how to improve the farmers exchange rate and strategy in overcoming poverty. Therefore, it is very relevant to assess the role of human resources in determining the exchange rate of farmers in East Tanjung Jabung Regency.

\section{Statement of the Problem}

Based on the explanation above, it is necessary to study in Tanjung Jabung District in east to the following aspects: 
1. How is the overview of farmers' food crops in East Tanjung Jabung Regency?

2. What factors determine farmers exchange rate in East Tanjung Jabung Regency?

3. How is the role of HR (human resources) to the exchange rate of farmers in East Tanjung Timur regency?

\section{Research objectives}

1. To know the description of farmers exchange rate in East Tanjung Jabung Regency.

2. To identify and analyze the determining factors of the exchange rate of farmers in East Tanjung Jabung Regency.

3. To analyse the role of HR (human resources) the exchange rate of farmers in East Tanjung Timur regency?

\section{RESEARCH METHODS}

\section{Scope of research}

This research is applicative (application research) so that the results of the research is more specific and focus on the framework and measurement design of research object. The method used/done in this study is the survey method. Based on the research objectives to be achieved, the method of determining the location of the research is deliberately (purposive), which is the center of the agricultural activities of food crops and horticultural in Tanjung Jabung Regency East, in consideration that the location of the research is an area with the productivity value of agricultural sub-sectors and the highest food crops and the majority of farmers' income is as farmers.

\section{Data Collection Methods}

This research uses the survey method. According to Silalahi (2010), that the survey is an attempt to acquire and group data and information from various sources.

The types of data collected in this study are cross section data types that are sourced:

1. Primary data, primary Data is taken directly in the field (farmers food crops in East Tanjung Jabung district).

2. Secondary data, i.e. data collected from agencies or institutions of institutions related to this research.

Data collection is done by:

1. Observation, observation is used to know the facts that occur in the research area based on their own observations. This observation is carried out directly by research in the place of Tanjung East Jabung researcher.

2. The interview, according to Singarimbun and Effendi (1995) The interview is a way to get information by asking directly to the respondent (farmer) by guiding the questionnaire that has been prepared.

3. Recording, which is data collection by recording the data available on the institution or institutions related to the research problem.

\section{Sample Withdrawal Methods}

The population in this research is all farmers ' food crops in East Tanjung Jabung Regency. Samples of this research are differentiated into two kinds of samples, namely 
regional samples (porposive sampling) and farmer samples (Randoms sampling). Sample area includes 5 Sub-Districts: 1) Rantau Rassau, 2) Muara Sabak Timur, 3) Geragai, 4) Nipah Panjang and 5) Berbak Sub-district (purposive sampling). Consideration of the area as the location of research is based on data from the agricultural office of Tanjung Jabung Timur, 5 sub-district is a region that is producing the highest level of production/ha (productivity) of all existing sub-districts and the number of people whose main search is the food crops farmers. While the sample of farmers chosen for interviewees is a simple randomized incidental selected or incidential simple random sampling.

While the size of the samples in each group or sub-district is assigned the same number of each district as many as 40 samples in consideration that the number and characteristics of sub-samples from to 5 sub-districts are assumed to be almost identical (not much different).

\section{Data Analysis Methods}

In analyzing the research data used qualitative-quantitative descriptive methods and inferences. The results of the collected research are measured and calculated on average frequencies and are cented. Next to calculate/measure farmers exchange rate (NTP)) food crops in East Tanjung Jabung District used the concept of subsistence with the following formula:

$N T S=\frac{\sum P_{x i} Q_{x i}}{\left(P_{y i} * Q_{y i}\right)+\left(P_{y j} * Q_{y j}\right)}$

Where:

NTS $=$ Subsistence exchange rate; PXi = Price of agricultural commodities to $\mathrm{I}$,

$\mathrm{QXi}=$ production of agricultural commodities to $\mathrm{I} ; \mathrm{PYj}=$ Product price consumption,

$\mathrm{PYj}=$ Production Input product price; $\mathrm{QYi}=$ number of consumption products,

$\mathrm{PYj}=$ number of production inputs.

To determine the influance of factors affecting the the farmer's exchange rate using multiple linear regression analysis with SPSS programs. The Data required is the area of Farmer's land, the amount of production, the sale price of food crops, fertilizer prices, pesticides and the exchange rate of farmers and horticultural crops by using the following equation:

$\hat{Y}=a+b_{1} X_{1}+b_{2} X_{2}+b_{3} X_{3}+b_{4} X_{4}+b_{5} X_{5}+e$

Where:

$\hat{Y} \quad$ : Farmer exchange rate

a : The Intercept coefficient

$b_{1}-b_{5}:$ Regression coefficient

$\mathrm{X}_{1} \quad$ : Land size (Ha)

$\mathrm{X}_{2}$ : Total Production $(\mathrm{kg})$

$\mathrm{X}_{3} \quad$ : Selling Price $(\mathrm{Rp} / \mathrm{k})$

$\mathrm{X}_{4} \quad$ : Fertilizer Price $(\mathrm{Rp} / \mathrm{kg})$

$\mathrm{X}_{5}$ : Pesticide Amount $(\mathrm{Rp} / \mathrm{Kg})$ and

e : Regression coefficient (Error) 


\section{FINDINGS AND DISCUSSION}

\section{Characteristics of farmers}

Age

Judging from the age of farmers, most (62\%) Aged between 36 to 55 years and about $22,5 \%$ or 45 respondents in young people between 26 and 36 years of age. The remaining 15.5 percent is over 55 years old. That is, judging by the age factor of farmers or the age of farmers is considered very productive age. Therefore, it is necessary to continue the efforts to increase farmers ' productivity through applied workshops or trainings, as well as through other applicative trainings. For more details the characteristics of respondents based on age can be seen in the following table:

Table 1. Characteristics of Respondents by Age per-Sub District

\begin{tabular}{|llccccc|}
\hline \multirow{2}{*}{ No } & Sub district & $\mathbf{2 6 - 3 5}$ & $\mathbf{3 6 - 4 5}$ & $\mathbf{4 6} \mathbf{- 5 5}$ & $\mathbf{> 5 6}$ & \multirow{2}{*}{ Total } \\
& & 7 & 11 & 15 & 7 & 40 \\
1 & RantauRasau & 7 & 7 & 17 & 9 & 40 \\
2 & NipahPanjang & 13 & 17 & 17 & 3 & 40 \\
3 & Geragai & 6 & 13 & 14 & 7 & 40 \\
4 & SabakTimur & 12 & 13 & 10 & 5 & 40 \\
5 & Berbak & 45 & 61 & 63 & 31 & 200 \\
\hline & Total & $\mathbf{2 2 , 5}$ & $\mathbf{3 0 , 5}$ & $\mathbf{3 1 , 5}$ & $\mathbf{1 5 , 5}$ & 100 \\
\hline
\end{tabular}

Source: Primary Data, processed

\section{Education level}

Judging from the last education of farmers in the East Tanjung Jabung District, whose School level education is the most of $36 \%$ or as many as 72 respondents. The well-educated Senior High School is a little more than the educated JSS which is respectively at $32.5 \%$ and $27.5 \%$, while the number of farmers whose education is still very little degree is only $4 \%$ or 8 people respondents. For more details can be seen in the following table 2.

Table 2. Characteristics of respondents based on education level

\begin{tabular}{|c|c|c|c|c|c|c|}
\hline \multirow{2}{*}{ No } & \multirow{2}{*}{ Sub District } & \multicolumn{4}{|c|}{ Education Level } & \multirow{2}{*}{ Total } \\
\hline & & ES & JHS & SHS & $\mathrm{Ug}$ & \\
\hline 1 & RantauRasau & 19 & 9 & 12 & - & 40 \\
\hline 2 & NipahPanjang & 12 & 13 & 14 & 1 & 40 \\
\hline 3 & Geragai & 7 & 13 & 14 & 6 & 40 \\
\hline 4 & SabakTimur & 13 & 14 & 12 & 1 & 40 \\
\hline 5 & Berbak & 21 & 6 & 13 & - & 40 \\
\hline & Total & 72 & 55 & 65 & 8 & 200 \\
\hline & Percents & 36 & 27,5 & 32,5 & 4 & 100 \\
\hline
\end{tabular}

Source: Primary Data, processed

Note:

ES = Elementari School; JHS = Junior High School; SHS=Senior High Scool $\mathrm{Ug}=\mathrm{Under}$ graduate 


\section{Number of Family Members}

Judging from the number of family members of the most abundant food crops and horticultural farmers $(69.5 \%)$ Consists of 3-4 people. This means they only have children one to two people. This phenomenon may indicate the success of the family Planning (KB) program in the East Tanjung Jabung Regency and also because of the relatively high awareness of farmers that the size of family members will be difficult to finance education and health as well as efforts to improve the family welfare. As an overview the number of family members of farmers and horticultural crops can be seen in table 3. Following:

Table 3. Characteristics of respondents by number of family members

Sub Districts of East Tanjung Jabung

\begin{tabular}{|llccccc|}
\hline \multirow{2}{*}{ No } & \multirow{2}{*}{ Sub Districts } & \multicolumn{6}{c}{ Number of Family Members } & \multirow{2}{*}{ Total } \\
\hline 1 & RantauRasau & 1 & 32 & 6 & 1 & 40 \\
2 & NipahPanjang & 4 & 26 & 10 & - & 40 \\
3 & Geragai & 5 & 34 & 1 & - & 40 \\
4 & SabakTimur & 5 & 26 & 9 & - & 40 \\
5 & Berbak & 7 & 21 & 12 & - & 40 \\
\hline Total & & 22 & 139 & 38 & 1 & 200 \\
\hline Percents & $\mathbf{1 1}$ & $\mathbf{6 9 , 5}$ & $\mathbf{1 9}$ & $\mathbf{0 , 5}$ & 100 \\
\hline
\end{tabular}

Source: Primary Data, processed

\section{Land Area}

One of the assets of farmers describing the potential development of agricultural business is the distribution of land tenure, the broader ownership will be the better opportunities for increased production and prosperity. The narrow land tenure conditions and the inequality of land causes smallholder farmers to increase their prosperity when relying on land-based livelihoods.

If the land of farming that is considered worthy can provide income for farmer households must be more than two hectares, then based on this study, in East Tanjung Jabung Regency is quite a lot of farmers who can support farmer households from farming land. Land ownership on two hectares is found in all sub-districts, which have a total research area of 77 respondents or $38.5 \%$ as shown in table 4 .

Table 4. Characteristics of respondents by land area per-sub districts

\begin{tabular}{|ccccccc|}
\hline \multirow{2}{*}{ No } & \multirow{2}{*}{ Sub Districts } & \multicolumn{5}{c|}{ Land Arrea (ha) } \\
\cline { 3 - 7 } & & $\mathbf{< 0 , 5}$ & $\mathbf{0 , 5 0}-\mathbf{0 , 9 9}$ & $\mathbf{1 , 0 0}-\mathbf{1 , 9 9}$ & $\mathbf{2 2 , 0 0}$ & Total \\
\hline 1 & Rantau Rasau & - & - & 28 & 12 & 40 \\
2 & Nipah Panjang & 2 & - & 23 & 15 & 40 \\
3 & Geragai & 1 & - & 26 & 13 & 40 \\
4 & SAbak Timur & - & 1 & 27 & 12 & 40 \\
5 & Berbak & - & 1 & 14 & 25 & 40 \\
\hline & Total & 3 & 2 & 118 & 77 & 200 \\
\hline & Percents & 1,5 & 1 & 59 & 38,5 & 100 \\
\hline
\end{tabular}

Source: Primary Data, processed 


\section{Job side}

Farmers of food crops in East Tanjung Jabung District almost entirely (90\%) Have a side job. Most (55\%) The work is mixed. This is especially because they are fully told that if it relies solely on the income of the main work such as rice farmers, its income is insufficient for the fulfillment of its needs.

The work of the mixture is, they work as a rice farmer and also as a worker, catching fish, trade and other labor. This means it depends on the job opportunities available to increase their revenue. However, on the other hand, there are still about $5 \%$ of those who do not have any side work or other work apart from the main job as a farmer of food crops.

If further traced, the side work is to be the head of the neighbor Rukun (RT), become a member of BPD, the business of boarding, stage and other work that is summarized in the category of work, which is about $3 \%$. For more details can be seen in the following table 5:

Table 5. Characteristics of respondents based on side work Per-Sub Districts

\begin{tabular}{|llccccccc|}
\hline No & Plant type & $\begin{array}{c}\text { Rantau } \\
\text { Rasau }\end{array}$ & $\begin{array}{c}\text { Nipah } \\
\text { Pjng }\end{array}$ & $\begin{array}{c}\text { Geragai } \\
\text { 1. }\end{array}$ & $\begin{array}{c}\text { SabakT } \\
\text { imur }\end{array}$ & Berbak & Total & Percents \\
2. & $\begin{array}{l}\text { Animal } \\
\text { husbandry }\end{array}$ & 2 & 27 & 20 & 7 & - & 56 & $\mathbf{2 8}$ \\
3. & Fishing & - & 2 & 3 & - & 4 & 9 & $\mathbf{4 , 5}$ \\
4. & Labor & 1 & 1 & 1 & 1 & 2 & 6 & $\mathbf{1}$ \\
5. & Trade & - & 2 & 1 & - & 1 & 4 & $\mathbf{3}$ \\
6 & Mix & 35 & 2 & 15 & 26 & 32 & 110 & $\mathbf{5 5}$ \\
7 & Others & - & - & - & 3 & - & 3 & $\mathbf{1 , 5}$ \\
8 & Non & 2 & 5 & - & 2 & 1 & 10 & $\mathbf{5}$ \\
\cline { 2 - 8 } & Total & 40 & 40 & 40 & 40 & 40 & 200 & 100 \\
\hline
\end{tabular}

Source: Primary Data, processed

Description:

1. deep coconut, palm oil, nut rubber

2. cows, chickens, goats, ducks, wallets

3. fish ponds, fish fishing, fishermen

4. Farm workers, factories

5. stalls/shops, trade around

6. Village apparatus, teacher Ngaji, Kos-kosan, cookers/Stage

\section{Side Income}

Income by farmers and horticultural crops in Tanjung Jabung Regency is largely (38\%) is at a range of $\mathrm{Rp} 500,000$ to $\mathrm{Rp} .3$ million (Rp. 500.000 - Rp. 3 million) and $21.5 \%$ are above $\mathrm{Rp} 5.0000 .000$,-(five million rupiahs) in planting season. This high income is mainly because they work not only on one field or focused on one job. 
On the other hand there are still farmers who are not motivated to add income other than the main work $(5 \%)$. This can be due to a lack of initiatives and some that may feel enough to have earned income. For more details can be seen in the following table 6:

Table 6. Characteristics of respondents by Side Income Per-District sideline

\begin{tabular}{|cccc|}
\hline No & $\begin{array}{c}\text { Side Income(Rp.000) } \\
\text { In Thousands Rupiahs }\end{array}$ & Respondents & Percentge \\
\hline 1 & Non & 10 & 5 \\
2 & $<500$ & 29 & 14,5 \\
3 & $500-1000$ & 32 & 16 \\
4 & $1100-2000$ & 33 & 16,5 \\
5 & $2100-3000$ & 31 & 15,5 \\
6 & $3100-4000$ & 14 & 7 \\
7 & $4100-5000$ & 8 & 4 \\
8 & $>5000$ & 43 & 21,5 \\
\hline & Total & 200 & 100 \\
\hline
\end{tabular}

Source: Primary Data, processed

\section{IDR=Indonesian Rupiah}

\section{Main Income}

The main income of farmers is diverse, there are very low income, which is less than Rp 5 million,-(five million rupiah) in planting season and some are income above or greater than Rp. 70.0000.000 (greater than seventy million rupiah) in planting season. Most farmers (65\%) Income ranges from Rp. 5.000.000 - Rp. 43.9 million,-season planting. More details can be seen on table 7 .

Generally, the higher-income farmers who are farmers who have a food crop (rice), while the low income are those who are the status of farmers with narrow/small land. This is mainly due to land area factor and selling price when harvesting.

Table 7. Characteristics based on major revenue respondents

\begin{tabular}{|c|c|c|c|c|c|c|c|c|}
\hline \multirow[b]{2}{*}{ No } & \multirow{2}{*}{$\begin{array}{c}\text { Main } \\
\text { Income } \\
\text { (Thausand } \\
\text { Rupiahs) } \\
\end{array}$} & \multicolumn{7}{|c|}{ Sub District } \\
\hline & & $\begin{array}{l}\text { Rantau } \\
\text { Rasau }\end{array}$ & $\begin{array}{c}\text { Nipah } \\
\text { Panjang }\end{array}$ & Geragai & $\begin{array}{l}\text { Sabak } \\
\text { Timur }\end{array}$ & Berbak & Total & $\%$ \\
\hline 1 & $<5000$ & 3 & 1 & 7 & 7 & 1 & 19 & 9,5 \\
\hline 2 & $5000-17900$ & 15 & 12 & 2 & 14 & 12 & 55 & 27,5 \\
\hline 3 & $18000-30900$ & 10 & 11 & 7 & 10 & 5 & 43 & 21,5 \\
\hline 4 & $31000-43900$ & 4 & 6 & 9 & 3 & 10 & 32 & 16 \\
\hline 5 & $44000-56900$ & 4 & 4 & 12 & 3 & 2 & 25 & 12,5 \\
\hline 6 & $57000-69900$ & 3 & 0 & 3 & 0 & 1 & 7 & 3,5 \\
\hline
\end{tabular}




\begin{tabular}{|ccccccccc|}
\hline 7 & $70000-83000$ & 0 & 3 & 0 & 1 & 2 & 6 & $\mathbf{3}$ \\
8 & $>83000$ & 1 & 3 & 0 & 2 & 7 & 13 & $\mathbf{6 , 5}$ \\
\hline & Total & 40 & 40 & 40 & 40 & 40 & 200 & 100 \\
\hline
\end{tabular}

Source: Primary Data, processed

If viewed from each sub-district apparently the income is better/higher in the subdistrict Berbak and Nipah Panjang. While the opposite of Geragai Sub-district is relatively lower, more details can be seen in the following image:

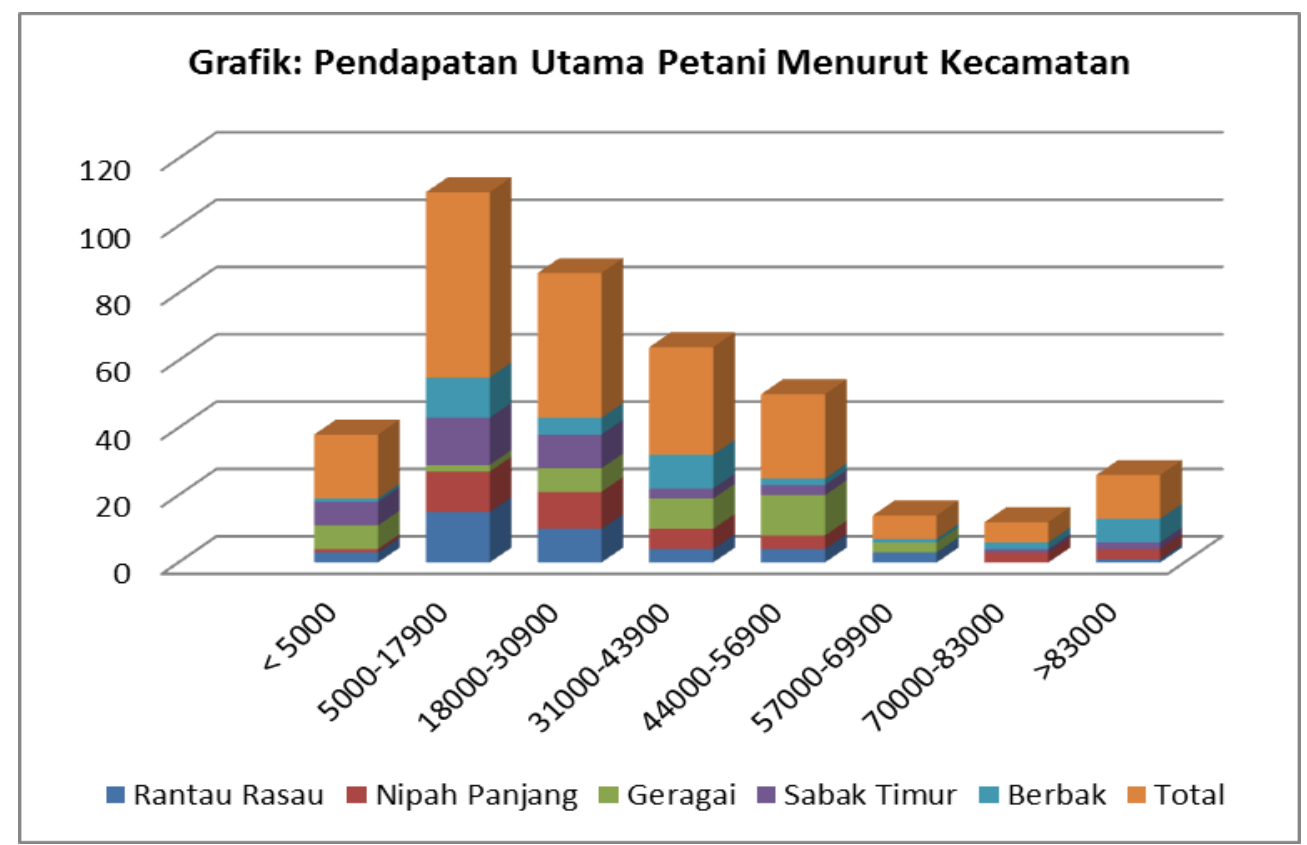

Figure 1. Composisi responde based On major revenue

\section{Farmer's exchange rate (NTP)}

Based on the results of the calculations using data taken at the end of the year 2018, obtained the average NTP for Tanjung Jabung Timur Regency based on five sub-districts used as a sample in this study namely Rantau Rasau Sub-district, Nipah Panjang, Geragai, Muara Sabak Timur and Berbak is at 108.07 percent. The the farmer's exchange rate calculated in this study is based on some of the most eminent commodity food crops in the district of east Tanjung Jabung.

Table 8. Acceptance, expenditure and exchange rate of farmers The Sub-district of East Tanjung Jabung Regency

\begin{tabular}{|clccc|}
\hline No & Sub District & $\begin{array}{c}\text { Total } \\
\text { Revenue } \\
\text { ofFarmers } \\
\text { Cropt (IDR) }\end{array}$ & $\begin{array}{c}\text { Cost of } \\
\text { Produktion and } \\
\text { Primery need } \\
\text { (IDR) }\end{array}$ & $\begin{array}{c}\text { Farmers } \\
\text { Exchage Rate } \\
\text { (NTP) }\end{array}$ \\
\hline 1 & Nipah Panjang & 33.059 .063 & 31.966 .085 & 1,0341918 \\
2 & Rantau Rasau & 26.763 .063 & 26.700 .802 & 1,0023318 \\
3 & Geragai & 48.632 .225 & 30.874 .250 & 1,5751711 \\
\hline
\end{tabular}




\begin{tabular}{|lllll|}
\hline 4 & Sabak Timur & 22.972 .225 & 19.627 .688 & 1,1703990 \\
5 & Berbak & 34.273 .042 & 37.541 .446 & 0,9129388 \\
\hline & Total & 33.139 .924 & 30.664 .586 & 1,0807235 \\
\hline
\end{tabular}

Source: Primary Data, processed

From the table above, it can be seen that almost all sub-districts in East Tanjung Jabung Regency The farmer's exchange rate (NTP) is at a point close to one hundred. This means that although farmers are still categorized as profit in the cultivation of agricultural crops and horticultural but the condition is very risky, because in addition to only comparable, also if subsidies and various assistance is not there, then farmers will tend to lose, except the district Geragai which the farmer's exchange rate its above $150 \%$. This is mainly due to the effectiveness of various government assistance, both the central government and local governments.

On the other side, Berbak subdistrict is still located at 91.29, meaning that farmers still tend to lose. This phenomenon is mainly due to the relative magnitude/high expenditure of production factors and primary needs. To realize that Farmer Exchange Rate is above a hundred, it should be sought to increase the effectiveness of local government cooperation (related agencies) with farmers and private sector to streamline farmers ' spending and in the effort to increase the income of farmers in food crops.

Human Resourches role is very dominant because in addition can manage the efforts ranging from preharbest handling to post Harberst handling (Post Harvest).

\section{CONCLUSION AND SUGGESTION Conclusion}

Based on the discussion in the previous chapter can be concluded:

1. The exchange rate of farmers in East Tanjung Jabung District based on the results of this study was obtained at 108.07. This figure shows that the farmer is in the condition of not losing, but very close to the number 100 means that if not addressed in earnest and continuously enhanced the solid cooperation between farmers themselves with elements of government (related agencies), private and community, then this figure will be under a hundred. Of the 5 sub-districts, one sub-district of which is the subdistrict of Berbak Ntlid is below a hundred (91.29).

2. The determining factors for the exchange rate of farmers in East Tanjung Jabung District are : the area of land, the number of production, selling price, seedlings, fertilizer, medicines and household expenditure of farmers.

3. The strategy to increase the farmer's exchange rate in East Tanjung Jabung Regency are: increase the effectiveness of seedlings assistance programs, fertilizers, medicines, and Alsintan, seek the stability of production prices through the formation of farmer groups, cooperatives and or business entities that can accommodate agricultural products or manage agricultural produce, so that farmers do not sell immediately the harvest even in low price

\section{Suggestion}

Because the farmer's exchange rate is still being mined, it is necessary to continue the effectiveness efforts of farmers ' cooperation, government (related agencies) and the private 
sector and the community to improve the Exchange rate for farmers of food cropsIn East Tanjung Jabung Regency (NTP).

\section{REFERENCE}

Arsyad, Lincolin. 1992. Development Economics, 2nd edition first printing, STIE YKPN. Yogyakarta

Barlowe R. 1978. Land Resource Economics. New Jersey (US): Prentice Hall.

BPS, East Tanjung Jabung Regency. 2014. Data and Information regency of East TanjungJabung. East Cape Jabung (ID): Central Statistic Agency of East Tanjung Jabung regency.

BPS Central Statistics District of East Tanjung Jabung. 2017. Gross Regional domestic product of East Tanjung Jabung Regency by Business field 2012 - 2016. https://tanjabtimkab.bps.go.id/publication/2017/08/07/6f5e81a82d9c25f4e1eef791/prod uk-domestik-regional-bruto-kabupaten-tanjung-jabung-timur-menurut-lapangan-usaha2012---2016. html

Dabukke FBM, Iqbal M. 2014. Thailand, India, and Japan's agricultural development policy and its implications for Indonesia. Akp. 12 (2): 87-101.

Simatupang, P. 2007. Critical analysis of the Paradigm and foundation framework of national food security policy. Agro Economic Research Forum, 25 (1), 1-18. 